\title{
9. DNEVI KADROVSKIH DELAVCEV SLOVENIJE Povežimo strategije z ljudmi Portorož, 13,-15, april 2005
}

$\mathrm{L}$ kdo bo torej uspešno vodil podjetja prihodnosti? smo se spraševali na 9. Dnevih kadrovskih delavcev, ki so potekali od 13. od 15. aprila 2005 v Portorožu v organizaciji podjetja GV Izobraževanje.

Kar 70 do 80 odstotkov nove vrednosti ustvarijo zaposleni s svojim delom, razumom, ustvarjalnostjo. Kritični produkcijski faktor je zelo majhen in tehta le približno 1,3 kilograma - to so človeški možgani. $\gg V$ svetu, kjer vsakdo kopira od vsakogar, res ni več pomemben kapital, temveč inovativnost, « je bila osrednja uvodna misel 9. posveta kadrovskih delavcev.

Znanje je že zdavnaj zamenjalo kapital pri doseganju konkurenčne prednosti. Zgodilo se je to, kar ni nihče prav zares verjel. Kapitalsko revnejša podjetja $\mathrm{z}$ velikim intelektualnim kapitalom s trga spodrivajo kapitalske mogotce. V vaših letih ne morete več zaslužiti denarja iz naravnih virov, lahko ga zaslužite le $\mathrm{z}$ znanjem. Znanje je moč in zato ni čudno, da smo se naenkrat znašli sredi hladne »vojne

$\checkmark$ svetu divja vojna za talente. znanja $\mathrm{ji}$, državami in posamezniki. Znanje se širi in ni ga več moč ustaviti, še manj olastniniti.

Vojna za talente med podjetji je torej odsev in praktična posledica hladne vojne znanja, kjer se trudimo pritegniti pozornost "lastnikov znanja in jih prepričati, da delajo za nas.

Podjetja potrebujejo »vrhunske možgane«, potrebujejo talente. Na področju informacij- ske tehnologije in farmacije vojna za talente divja že vrsto let. Leta 2000 je bilo na IT področju prostih 500.000 delovnih mest, po napovedih pa se bo leta 2002 to število povečalo na 1,6 milijona. Vojna za najboljše se seli tudi na druga področja. Do leta 2025 bo Evropska unija potrebovala kar 150 milijonov priseljenih delavcev, če bo želela zadostiti potrebam po zaposlovanju in še naprej gospodarsko rasti.

Zaposlenih ne moremo prisiliti, da bodo svoje znanje delili z organizacijo, lahko pa ustvarimo takšno okolje, $v$ katerem bodo svoje znanje radi delili z drugimi. Znanje samo po sebi namreč še ni jamstvo uspeha. Ljudje morajo biti tudi pripravljeni znanje uporabiti. Resnično je prišel čas, ko moramo več pozornosti posvetiti kompetencam, je bil eden izmed sklepov 9. Dnevov kadrovskih delavcev, torej znanjem, spretnostim, veščinam in vrednotam ter prepričanjem ljudi. Pojem kompetenc bi zlahka primerjali z učenjem vožnje kolesa. Če se torej želimo naučiti voziti kolo, moramo najprej imeti določeno tehnično zanje o delovanju kolesa. Toda to ni dovolj, razviti moramo še spretnost lovljenja ravnotežja, da se obdržimo na dveh kolesih. Toda tudi to še ni jamstvo, da se bomo s kolesom res vozili. Razviti moramo še vrednote, npr. da z vožnjo kolesa ne onesnažujemo okolja, in splošno prepričanje, da je kolesarjenje zdrav način življenja. Pot do dejanske uporabe kolesa je torej dolga, ravno tako kot pot od znanja do 
uspešne izvedbe. Uspešnosti torej ne moremo upravljati, ne da bi poznali celoto. V organizacije prihajajo ljudje tudi $\mathrm{z}$ »dušo«, torej $\mathrm{s}$ svojimi vrednotami, potrebami, željami, ambicijami, sposobnostmi ... Torej bi bilo učinkoviteje, če bi se menedžerji večkrat vprašali, kakšen je donos na investicijo v človeški kapital.

Skladno z razmišljanjem o kompetencah smo se posvetili tudi razmišljanju o ključnih kadrih: Kdo so ključni kadri v podjetju in kako z njimi ravnati, da jih obdržimo in da bodo resnično lahko prispevali $k$ uspehu organizacije? Kako naj torej povežemo poslovne strategije z ljudmi? Strokovnjaki so bili enotnega mnenja. Najprej je potrebno narediti kadrovsko analizo, šele nato se lotiti oblikovanja poslovnih strategij, ne pa obratno, kot je slaba razvada mnogih, če ne vseh slovenskih podjetij.

Najprej se bo treba zazreti vase, torej v sam profil kadrovskega strokovnjaka, so sklenili udeleženci posveta, in več vlagati $v$ razvoj kadrovske funckije ter predvsem verjeti, da lahko s kadrovskimi aktivnostmi prispevamo dodano vrednost k organizaciji.

Po letu 1990 večina podjetij namreč že meri uspešnost kadrovske funkcije. Meri se torej moč človeškega kapitala, izvajajo se raziskave in študije vloge kadrovske funkcije na makro ravni, torej na ravni ekonomije neke države. Tudi v Sloveniji smo uvedli uravnotežene kazalnike uspešnosti (BSC), ki pri določanju uspešnosti podjetja enakovredno upoštevajo tudi stanje človeškega kapitala, uvedli metodologijo za izračun donosa na investicijo (ROI) v kadrovski službi ... Kadrovska služba $v$ marsikaterem podjetju/organizaciji postaja profitni center, katere glavna naloga je "proizvajati« zadovoljne, učinkovite in uspešne zaposlene.

V svetovnem merilu je že v 40 odstotkih podjetji kadrovski menedžer član uprave, v Sloveniji pa zaostajamo za dobro polovico, le 20 odstotkov kadrovskih menedžerjev je vključenih $\mathrm{v}$ strateško odločanje. Vključenost $\mathrm{v}$ članstvo uprave pa je glavni pokazatelj, kako so in kako smo pripravljeni povezati strategije $\mathrm{z}$ ljudmi. In ravno povezanost poslovnih strategij z ljudmi bo odločala o bodočih zmagovalcih, je bilo prepričanih več kot 300 udeležencev 9. tradicionalnega posveta Dnevi kadrovski delaveev. Za 10. obletnico posvetovanja, ki bo aprila 2006 v

Kažejo se zahteve
po večji profesio-
nalizaciji kadrov-
ske funkcije.
Portorožu, pa so organizatorji že napovedali tudi novo akcijo - iskali bodo najvplivnejšega kadrovskega menedžerja leta.

Mag. Daniela Brečko

GV Izobraževanje 